\title{
Massive Endometriosis in Two Rhesus Monkeys
}

\author{
Junzo SAEGUSA, Yoshikuni TANIOKA*, and Hitoshi KOIZUMI* \\ National Institute of Industrial Health, 6-21-1, Nagao, Tama, Kawasaki 214, \\ Japan and "Central Institute for Experimental Animals, Nogawa 1430, \\ Miyamae, Kawasaki 213.
}

(Received 13 January 1989/Accepted 28 Februany 1989)

\begin{abstract}
Massive endometriosis was found in two rhesus monkeys during a chronic toxicological experiment. These cases had metastatic lesions in lymph nodes in addition to the foci on the serosal wall of pelvic organs. Invasion to the intestinal mucosal layer was also noted in a case. These observation indicated that endometriosis in the rhesus monkey might behave like a malignant neoplasm.
\end{abstract}

Endometriosis is a disease characterized by ectopic implantation of endometrial tissues outside the uterine cavity. It occurs only menstruating species such as humans and other primates. Endometriosis is not uncommon in rhesus monkeys, and it has been reported as a sequela to hysterotomy with additional effects of ovarian steroids $[1,3,4,6,9,10]$ and as a latent effect of irradiation $[1,6,7,9,11,12]$. In most of the reported cases in rhesus monkeys, the lesion was limited to the wall of pelvic organs $[1,3,6-10,12]$. The severe cases presented in this report are of particular interest due to widespread dissemination of the endometrial tissues without prior histories of uterotomy nor irradiation.

The cases were 2 of the 40 female wildcaught rhesus monkeys imported from India in 1978. The ages of the animals were estimated from 4 to 7 years by dentition. After physical and bacteriolgical examinations, the animals were supplied for a experiment to observe the long term effects of oral exposure of a heavy metal when accompanied by malnutrition. During the experiment the animals were kept individually in steel stainless cages. The cases presented in this study were given $150 \mathrm{~g}$ of vitamin $\mathrm{D}$ deficient pellets with or without the metal and $900 \mathrm{ml}$ of fresh tap water per a day, and were allowed to take ad libitum. In ad- dition, 30mg of powdered ascorbic acid were addedin the drinking water 3 times a week as a vitamin $C$ supplement. No attempt of irradiation, hysterotomy nor hormone therapy had been made during the experiment.

Case 1 which was from the experimental group lost body weight progressively after 86 months of the experiment and both anemia and abdominal distention were noticed at the 90 th month. Since emaciation and weight loss were prominent thereafter, she was euthanatised and autopsied at the 99 th monhth. Case 2 which was from the control group lost body weight slightly but progressively after 86 months of the experiment. Recurrent vomiting was observed for 2 weeks at the 96 th month. After the 100 th month, she was emaciated with severe weight loss, anemia as well as abdominal swelling. She was euthanatized and autopsied at the 103 th month.

At the necropsy, case 1 had small amount of bloody ascites. Firm nodules of varing sizes were seen on the mesentery. There was a firm nodule of $3 \mathrm{~cm}$ in diameter at the ileum, which adhesed with other part of small intestine. Fibrous thickening of the serosa was noted at uterus, urinary bladder and colon. Case 2 contained about $450 \mathrm{ml}$ of bloody fluid in the pelitoneal cavity. All abdominal organs were bound together. The walls of these organs were 
thickened and fibrous, being hardly separated by fingers.

Microscopically, extrauterine proliferation of endometrial tissues, which were morphologically similar in both cases, were seen at the serosal surface of small and large intestine, ovary, oviduct, uterus, urinary bladder and mesentery. In case 2 the foci were also detected at serosa of stomch and liver, and parietal peritoneum. The lesions were characterized by normal appearance of endometrial glands lying with the typical endometrial stroma and occasional blood vessels (Fig. 1). Papilliform process were formed on the serosa of oviducts and ovaries of case 1. Firm nodules found in the mesentery of case 1 were typical endometrial glands with a lot of stroma containing small amounts of blood and/or cell debris.

In addition to serosal lesions, endometrial glands without stroma proliferated in the mesenteric lymph nodes of both cases and their metastatic implantation was also detected in pulmonary lymph nodes of case 2 (Fig. 2). The glands were formed by a single layer of cuboidal to low columnar and foamy epithelial cells excreting alcian-blue and/or periodic acid-Shiff positive mucus. Endometrial glands proliferated in the muscularis of the small and large intestine in both cases. The glands in the muscularis consisted of cuboidal epithelial cells with rare stroma, while those on the serosa consisted of columnar ones with abundant sroma. In case 1 , endometrial glands further invaded the

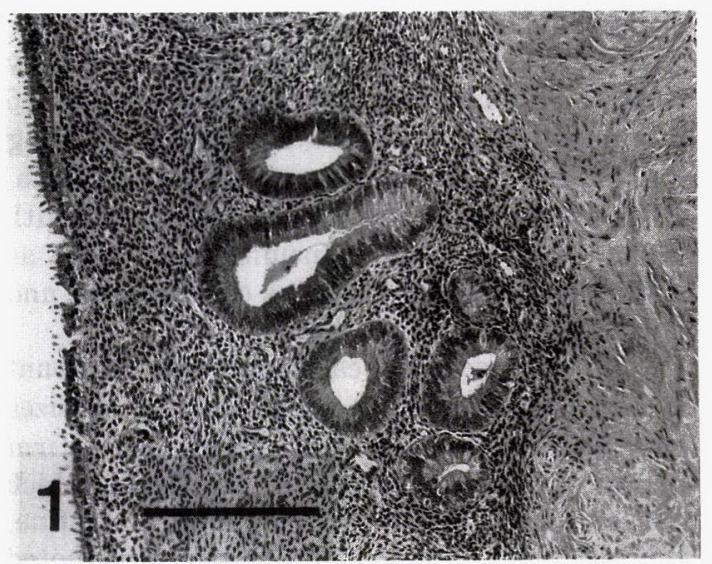

Fig. 1. Endometrial tissues on the serosa of urinary bladder of case 2 HE stain $\mathrm{Bar}=200$ $\mu_{\mathrm{m}}$

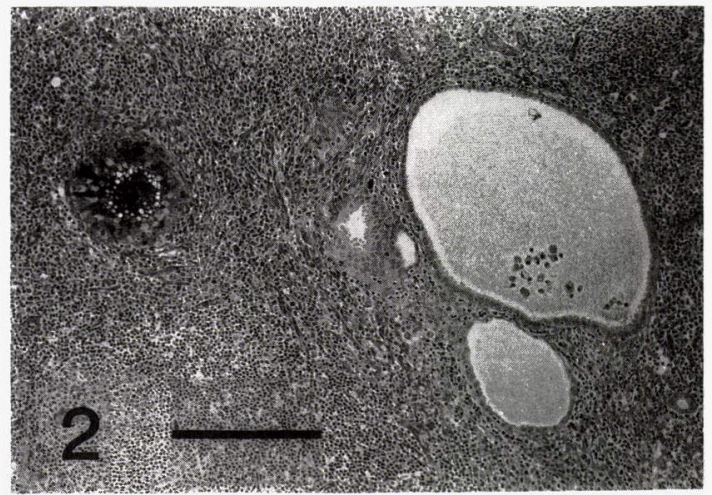

Fig. 2. Metastatic implantation of endometrial glands in plumonary lymph node of case 2 Note a gland (upper left) containing alcianblue posive mucus Alcian-blue and periodic acid-Shiff stain $\operatorname{Bar}=300 \mu \mathrm{m}$

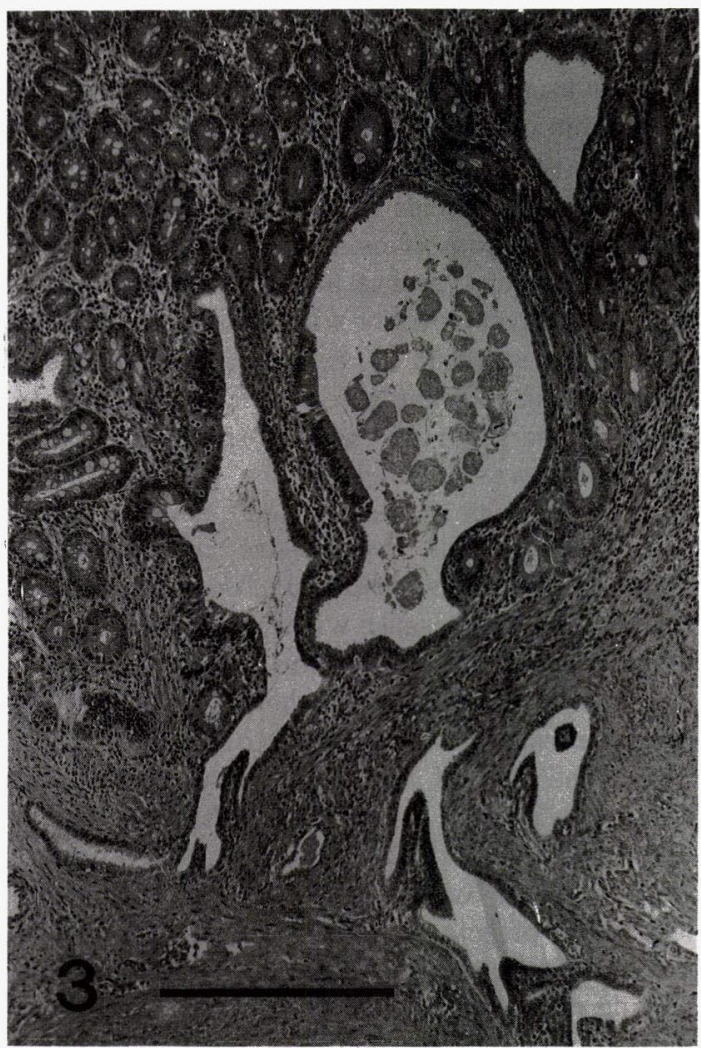

Fig. 3. Endometrial glands in muscular and mucosal layer of small intestine of case 1 Note necrotic intestinal epithelia detached in the gland $\mathrm{HE}$ stain $\mathrm{Bar}=300 \mu \mathrm{m}$ 
mucosal layer of the small intestine, where intestinal epithelia were oppressed and detached (Fig. 3).

As a coexistent pathology, pneumonia caused by aspiration of foreign materials was detected in both cases. Diffuse necrosis of ovary was noted in case 2 .

Except for a few spontaneous endometriosis [8], most cases in rhesus monkeys have been thought to be the sequela of hysterotomy or chronic effects of irradiation $[1,3,6$, 7, 9-12]. Present two cases, however, were free from these treatment at least for 9 years as far as we are concerned. These results prompted us to examine other monkeys used in the same experiment and, in fact, we could find more than $50 \%$ of the monkeys were suffered from this disease (manuscript in preparation), suggesting that neither hysterotomy nor irradiation might be necessary for this disease to occur.

Various hypotheses have been made as to the etiology including 1) serosal metaplasia of celomic epithelium, 2) transformation of Wolffian duct cells, 3) lymphatic or hematogeneous metastasis and 4) retrograde menstration with implantation of endometrial tissues. Recently deficiency of cellular immunology has been implicated as a possible contributing factor to endometriosis [5]. The heavy metal intoxicated to the monkeys was unlikely to be a contributing factor to this disease since one case was from the control group and the other was from the experimental group. Present cases bad been vitamin $D$ deficient for several years, therefore, there is a possibility that they might have been immunodeficient because 1,25dihydroxyvitamin D 3 which is the active metabolite of vitamin $\mathrm{D}$ has been reported to activate the monocyte-derived macrophages [2].

While foci of the most cases reported were limited on the serosal wall of the pelvic organs, metastatic endometrial lesions have been reported $[7,11]$ and were noticed in the present cases. In our cases, the endometrial glands were seen not only in the mesenteric lymph nodes but also in the pulmonary nodes, suggesting that they could distantly metastate via lymphatic system. It was also noted that they invaded and destructively grew in muscular and mucosal layer of the intestine. This is the first case of endometriosis involved intestinal mucosa as far as we are concerned. These observation strongly indicated that endometriosis in rhesus monkeys might behave like a malignant neoplasm whereas any morphological evidence of malignancy such as anaplastic or mitotic figures could not be noticed.

Authers thank Mrs. H. Kubota for her expert technical assistance.

\section{References}

[1] Bertens, A. P. M. G., Helmond, F. A., and Hein, P. R. (1982). Lab. Anim 16, 281-284.

[2] Cohen, M. S., Mesler, D. E., Snipes, R. G., and Gray, T. K. (1986). J. Immunol, 136, 1049-1053.

[3] DiGiacomo, R. F. (1977). Vet. Pathol, 14, 539-546.

[4] Dizerega, G. S., Barber D. L., and Hogden, G. D. (1980). Fertil. Steril, 33, 649-653.

[5] Dmowski, W. P., Steel, R. W., and Baker, G. F. (1981). Am. J. Obest. Oyne col, 141, 377-383.

[6] Eisenfeld, A. J., Gardner, W. U., and van Wagenen, G. (1971). Amer. J. Obstet. Gyne col, 109, 124-130.

[7] Fanton, J. W., Hubbard, G. B., and Wood, D. H. (1986). Am. J. Vet. Res., 47, 1537-1541.

[8] Lindberg, B. S. and Busch, C. (1984). Upsala J. Med. Sci. 89, 129-134.

[9] Mackenzie, W. F. and Casey, H. W. (1975). Amer. J. Pathol, 80, 341-344.

[10] McCann, T. O. and Myers, R. E.(1970). Amer. J. Obstet. Oynecol, 106, 516-523.

[11] McClure, H. M., Ridley, J. H. and Graham, C. E. (1971). J. Med Assoc. Ceorgia, 60, 11-13.

[12] Splitter, G. A., Kirk, J. H., MacKenzie, W. F., and Rawlings, C. A. (1972). Vet. Pathol 9, 249-262. 


\section{アカゲサルにみられた子宮内膜症の 2 例}

$$
\begin{gathered}
\text { 三枝 順 三・谷 岡 功 邦*・小 泉 均* } \\
\text { 労働省産業医学総合研究所 } \\
*(\text { 貼 }) \text { 実験動物中央研究所 }
\end{gathered}
$$

慢性毒性実験に用いたアカゲサル2 例に重篤な子宮内 膜症を観察した。病巣は 2 例とも骨盤腔荗器の漿膜面の みならず，消化管筋層や腸間膜リンパ節にも見られた。 加えて 1 例では小腸粘膜層への浸潤を，他の 1 例では肺
門リンパ節での転移性增殖も認められた。今回の観察か らアカゲサルの子宮内膜症は悪性腫瘍のような動態をと りらることが示㖫された。 